\title{
Research on the early prehistory of Fiji
}

\author{
Atholl Anderson \\ Department of Archaeology and Natural History, The Australian National University \\ Geoffrey Clark \\ Department of Archaeology and Natural History, The Australian National University
}

\section{Introduction}

This volume describes results of a research program on the early phases of prehistory in Fiji. The research began in 1995 as a collaborative project of the ANU and the Fiji Museum entitled 'Prehistoric colonisation and palaeoenvironment of Fiji' (Anderson et al. 1996). The initial emphasis was on the period beginning about $5000 \mathrm{BP}$ and extending up to about $2000 \mathrm{BP}$, with the objective of studying the pre-human landscape and then the arrival, spread and environmental impact of human colonisation. At the time, human colonisation was thought to begin somewhere between 3000 and 4500 BP, depending on whether archaeological (3200$3700 \mathrm{BP})$ or paleoenvironmental (4000-4500 BP) data were preferred, and the colonising Lapita phase was regarded as persisting up to about 2000 BP (Frost 1979:64; Gibbons and Clunie 1986; Southern 1986; Davidson et al. 1990:131; Davidson and Leach 1993:102-103).

Our initial fieldwork involved sediment coring for pollen, July-August 1995 in Viti Levu and Vanua Levu, including at sites where previous data had suggested unusually early dates of possible human impact (Hope and Anderson 1995). During the first season of archaeological fieldwork, in 1996, Clark began doctoral research on the early and middle phases of Fijian prehistory with the objective of studying transformations that led from Lapita towards a more distinctly Fijian cultural facies (Clark 2000). Thus, the Fiji project was broadened, and renamed 'The Early Prehistory of Fiji Project' (abbreviated to the EPF). Its objectives were to consider initial colonisation and its effects, and later transformations before the last millennium of Fijian prehistory: approximately equating to the Sigatoka and Navatu phases in the standard sequence (Green 1963a). Papers on themes of the Fiji project have been published already, notably on the chronology and modulation of colonisation (Anderson and Clark 1999; Anderson 2001; Anderson et al. 2001a; Anderson et al. 2006), intra-archipelagic dispersal (Clark and Anderson 2001), and aspects of faunal (Worthy et al. 1999; Anderson et al. 2001b) and vegetation change (Hope et al. 1999), and inland (Anderson et al. 2000) and small-island (Clark et al. 2001) settlement, among others. 
Our main intention in the current volume, consistent with the aim of Terra Australis, is to present and interpret the basic data of the project. In this chapter, we describe the background to the project as it was seen in 1995 .

\section{The Fiji Islands}

Fiji lies in an area of 570,000 sq. $\mathrm{km}$ of the Central Pacific Ocean, $12-22^{\circ} \mathrm{S}$, with the main islands at $16-17^{\circ} \mathrm{S}$. At 18,272 sq. $\mathrm{km}$, it is more like Vanuatu (14,760 sq. km) and New Caledonia (19,060 sq. km) than Tonga (748 sq. km) or Samoa (2850 sq. km), its main regional neighbours. It has 300 to 500 islands, depending on how they are counted (a common figure being 330), of which 110 are inhabited. Viti Levu (10,429 sq. km) and Vanua Levu (5556 sq. $\mathrm{km}$ ) are the largest (Pernetta and Watling 1979). In addition to these geologically complex volcanic and sedimentary islands, there are high volcanic islands and various coral limestone islands, upraised or as atolls. The geological complexity of Fiji arises from its position on the continental side of the Andesite Line (Figure 1), either directly on the Indo-Australian plate, or on an independent micro-plate which is being deformed by the movement of the IndoAustralian and Pacific plates along a subduction zone north and east of Fiji, in fact $1000 \mathrm{~km}$ east in the Tonga trench (Nunn 1994a:37). Viti Levu is the oldest island in the archipelago, dating to Late Eocene to Early Oligocene age (Rodda 1994), but it is not known whether it was exposed terrestrially at that time. Land was certainly present during the deposition of the Wainimala Group (Late Oligocene-Middle Miocene), and probably has been continuously present since about 16 million years ago (Chase 1971; Rodda 1994). The land area was about 50\% larger than it is now during the last glacial era, when Vanua Levu, Taveuni and Viti Levu formed a single large island (Watling 1982). Subsequently, sea level rose to about $1.5 \mathrm{~m}$ to $2 \mathrm{~m}$ above present at 4000-3000 BP (Nunn 1999:230) and then receded to complete the modern topography.

Fiji divides into two geographical provinces, the western province, which is dominated by large islands, and the eastern province, east of a line from Taveuni to Kadavu, which is made up entirely of small islands, including the Lau Group, which lies equidistant between the western province and Tonga. The main islands are rugged rather than mountainous, rising generally to 500-800 m, with small areas about $1000 \mathrm{~m}$ in altitude. There are two major river catchments, the Rewa and Sigatoka, both on Viti Levu, which, with the Ba, provide good access into the interior. The climate is tropical, with average daily temperatures remaining in the range 22$26^{\circ} \mathrm{C}$ all year round, but there is considerable variation in precipitation. Rainfall is highest in southeastern, or windward, districts, about 3000-6000 mm per annum, depending on altitude, and up to 13,000 mm per annum in the mountains of Taveuni. Associated with it in the natural state are dense rainforests. Northwestern districts get about half that rainfall and sustain dry forest and savannah. There is a wet season, November to April, during which 10 to 15 cyclones track across Fiji from the northwest each decade, sometimes causing major flooding, windfall and erosion.

If the main impression of the late Holocene environment of Fiji is of its variety, then a similar idea has permeated the common view of its people and culture. Human colonisation began in the late Holocene with Lapita migrations from the west, after which, in ways very poorly understood, there were changes that resulted in the Fijian people and culture encountered by Europeans. Abel Tasman, the first European visitor, sailed through the northeastern islands of Fiji in January 1643, and the Master of the Resolution left some presents on a beach at Vatoa in July 1774. The earliest regular contact seems to have been in western Vanua Levu, during the sandalwood rush, 1804-1810, and sustained interaction was associated with the trade in beche-de-mer, 1820s-1850s (Howe 1984:258-259). As a result of these encounters, the Fijian 
people and culture were perceived to be a mixture of Polynesian and Melanesian elements. There was regular contact between eastern Fiji and Tonga, and to a lesser extent with Samoa, so some mixing of populations was expected. William Mariner (Martin 1817 II:194, 199) found that the Tongans got their canoes, and learned much about the manufacture of them, from the Fijians, while the earthenware pots used in Tonga came from Fiji, and subsequent historical research has produced evidence of a thriving exchange network among Samoa, Tonga and Fiji (Kaeppler 1978). However, the idea of racial and cultural mixing went well beyond that.

The philologist Horatio Hale (1846:194) regarded Fijians as primarily Melanesian but derived through Papua, which included some Malaysian elements, and augmented by Malaysian

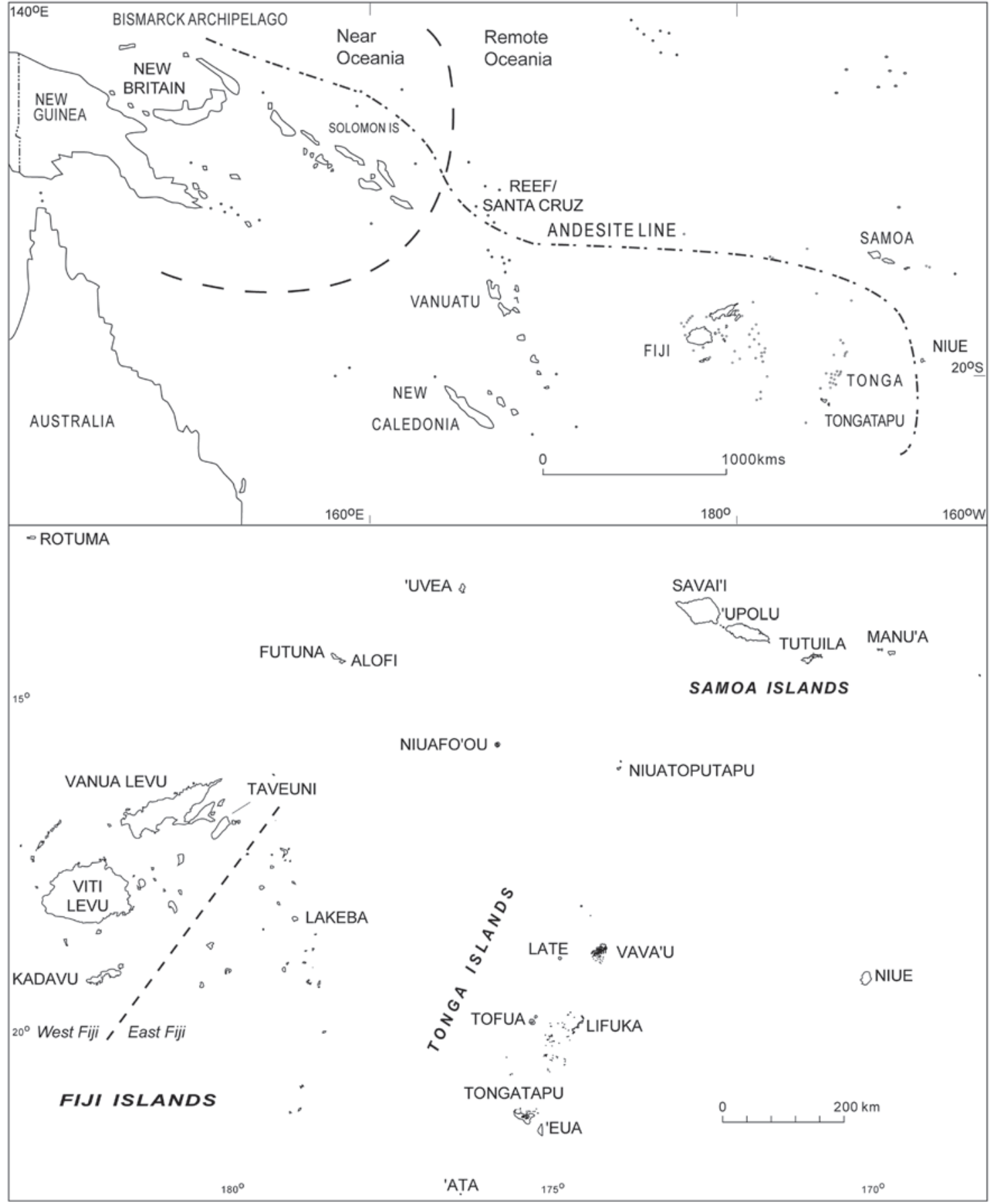

Figure 1. Map of the West and Central Pacific (top) and Fiji-West Polynesia (bottom). 
influence through Polynesia. Similarly, Howells $(1973: 158,168)$ placed Fiji in Melanesia but argued that the population: 'should be viewed as Melanesianized Polynesian rather than the reverse'. Linguists, however, placed Fijian in the Central Pacific subgroup of Oceanic languages. In this assemblage, otherwise entirely of conventional Polynesian languages, Proto-Central Pacific was located in Fiji and developed into a dialect chain that split into Rotuman, Fijian and West Polynesian languages (Pawley and Ross 1995:53-54). On that ground, Fiji was placed in Polynesia. Archaeological opinion, founded on the assumption that Lapita culture was spread by people of predominantly 'southern Mongoloid' origin (Bellwood 1996), proposed that Melanesian connections generally came later, and relatively weakly, to Fiji compared with Vanuatu and New Caledonia, the relative influence of these extracting Fiji from the remainder of historical 'Island Melanesia' (notably in Spriggs 1997).

The matters bound up in these views are far more complex than outlined here, but the point about Fiji being in a marginal or transitional position (e.g. Frost 1979) between Melanesia and Polynesia (leaving aside here the history and validity of those concepts; see Clark 2003) was basic to archaeological interest in the archipelago when our project began. The issues centred on the Navatu phase - in Green's (1963a) Fijian sequence dating 100 BC-AD 1100, and situated between the Sigatoka phase, which was seen as ancestral Polynesian, and the Vuda and Ra phases, regarded as exhibiting Melanesian culture. Both the ways in which the transition was conceptualised and its empirical nature remained very much open to debate (Hunt 1986).

Field research on Fiji's early prehistory, human and environmental, also had comparative value for the wider Central Pacific (Fiji-West Polynesia, also the eastern Lapita region). There had been frequent archaeological research on Lapita in Tonga since 1957 (Golson 1961; Groube 1971; Poulsen 1987; Kirch 1988), and a substantial project, based at Simon Fraser University, was underway in the early 1990s (Dickinson et al. 1994; Shutler et al. 1994). Only one Lapita site was known in Samoa, and it was underwater (Jennings 1974; Green and Richards 1975), but new efforts were being made to refine its chronology. Lapita-related fieldwork was in a quiet phase in Fiji by the early 1990s, but accelerated erosion at Sigatoka prompted renewed attention (Hudson 1994; Petchey 1995; Burley 1997; Wood et al. 1998). Some progress had been made in respect of faunal extinctions around the period of human advent in Tonga (Pregill and Dye 1989; Pregill 1993; Steadman 1993; Koopman and Steadman 1995), and there were sparse records from Lakeba (Best 1984), creating a potential basis for comparison. Investigation of vegetation changes in the prehistoric human era, however, had hardly begun (Hope et al. 1999). There were no records from Samoa, only a small project on mangrove pollen directed at sea-level issues in Tonga (Ellison 1989), and preliminary work in Fiji (Latham 1983; Southern 1986; and a project underway on Totoya Island by Clark et al. 1999).

The prehistory of Fiji in the post-colonisation period was also enigmatic, with potential stylistic influences from Southeast Asia and several Melanesian Islands (New Guinea, Solomon Islands, Vanuatu, New Caledonia) seen in Fijian ceramics (Gifford 1951:224, 236-237; Solheim 1952a, b; Frost 1970:252; Garanger 1971; Vanderwal 1973:209; Golson 1974:568, 573). Largescale investigations on Lakeba Island by Best $(1984: 216,493)$ suggested a ceramic record that had received inputs from New Caledonia and Vanuatu, and a broader pan-Melanesian ceramic style was suggested by Wahome $(1997,1998: 189)$, who proposed that ' . . contacts between the various regions of Island Melanesia continued through the Lapita, post-Lapita, late prehistoric times and after'. Navatu phase sites containing ceramics and material-culture items were studied to examine unresolved issues relating to the cause and sequence of prehistoric culture change in Fiji. 
Within Fiji, therefore, the main archaeological research focus at the beginning of the EPF was, first, the timing, nature, spread and impact of Lapita colonisation and, second, the definition, timing and causes of change through the Navatu phase. There was clearly a need to resolve questions about the chronology of Lapita and Navatu sites, and their distribution on islands of different sizes and types and coastally versus inland. In such a large and diverse archipelago, we also hoped to gain some insight into the dispersal of initial colonists through the Fiji Islands. The existence of substantial areas of limestone held out the promise of locating remains of extinct faunas, with the terrestrial ecological diversity of prehistoric fauna used to investigate the directions and rate of human impact on the botanical landscape. Thus the Fiji project was divided into three areas of research: faunal change, landscape change and early archaeology. The background, objectives and fieldwork of each are described briefly here.

\section{Faunal change}

The modern vertebrate fauna of Fiji is characterised by a lack of terrestrial mammals, as in other Pacific Islands, but it has six species of bats (Flannery 1995). Fruit bats are mainly of Pteropus spp., but also include Pteralopex acrodonta, which otherwise occurs only in the Solomons. Historically, the Fijian archipelago had 69 indigenous breeding land birds, 47 on Viti Levu. About 56\% of the land birds are endemic, yet few are as distinctive as might be expected in an avifauna from relatively old oceanic islands ('oceanic' meaning islands beyond a continental shelf). Even more unusual for an oceanic island is the fact that few species are known to have become extinct historically. Prominent larger taxa (Ryan 2000) include the reef heron (Egretta sacra), the collared lory (Phigys solitaries), two species of musk parrots (Prosopeia spp.), several fruit doves (Ptilinopus spp.) and their common predator the peregrine falcon (Faico peregrinus), the banded rail (Gallirallus philippensis) and the swamp hen (Porphyrio porphyrio). The avifauna of Fiji is most similar to that of Tonga and Samoa, with overlap of many species in the Lau Group (Watling 1982).

There is a diverse herpetofauna of frogs (Platymantis, 2 spp.), iguanas (Brachylophus, 3 spp.), geckos (9 spp.), skinks (9 spp.) and snakes (2 spp.). This fauna contains several endemic species that have no equivalents on truly oceanic islands, including two Platymantis frogs which are terrestrial, salt-intolerant taxa for which over-water dispersal seems unlikely. Their nearest relatives are in the Solomon Islands archipelago (Gorham 1965; Gibbons 1985). Of the iguanas (Brachylophus spp.), one is shared with Tonga, but otherwise no close relatives occur elsewhere. One snake, Ogmodon vitianus, is an endemic monotypic genus, while the boid Candoia bibronii is more widespread (Gibbons 1985). Interestingly, the Fijian invertebrate fauna retains a number of very large taxa, including giant stick insects (Hermarchus spp.), coconut beetles (Olethrius tyrranus) and longhorn beetles (Xixuthrus spp.), which seem to have survived predation by introduced rats (Ryan 2000).

The low incidence of historical extinctions and the scarcity of prehistoric extinctions (exceptions were remains of two megapodes and a pigeon) of relatively large-bodied terrestrial fauna compared with evidence from Tonga and several other Pacific islands (Balouet and Olson 1987; Steadman 1994, 1995; Steadman et al. 2000) begged the question about the faunal history of Fiji. Was a substantial sector of the terrestrial fauna (including land birds) missing from the historical and archaeological record? If the fauna existed, had it gone extinct before the arrival of people, possibly as a result of biogeographical changes resulting from post-Pleistocene sea-level rise? Alternatively, were faunal extinctions culturally coincident? These matters were set down for investigation, primarily by Worthy, in fieldwork involving survey and excavation of sediments preserved in cave sites (Worthy and Anderson 1999; Worthy 2000), mostly in the limestones of Viti Levu (Gilbert 1984). 


\section{Fieldwork}

In June 1997, there was a preliminary survey of caves in the lower and middle Sigatoka Valley and in September-October 1997, there was a survey of caves in the upper Sigatoka, and on Navo Island. In March-April 1998, Volivoli, Tuvu, Tau and Joskes Thumb were investigated and, in September-October 1998, research shifted mainly to the Wainibuku area near Suva. In November 1999, sites inland from Nadi were visited, along with caves in the Wainibuku Valley, and at Delaniqara at Wailotua. Research also occurred on Vatulele Island.

\section{Landscape change}

Fiji has strong floristic links to the west, with $90 \%$ of its genera occurring in New Guinea (Ash 1992). Dense tropical rainforest was the main prehistoric vegetation cover in windward districts of Fiji. It included stands of gymnosperms, notably Agathis macrophylla (A. vitiensis, dakua makadre), Dacrydium nidulum (yaka) and the cycad Cycas rumphii (logologo), as well as Cyathea tree-ferns, several hundred species of ground ferns such as the edible sovanigata (Asplenium australasicum) and some palms such as Veitchia joannis and Pritchardia pacifica. West and north coasts have a dry season and annual rainfall of 1500-2000 mm. Late Holocene rainfall was sufficient to support dry forest, dominated by Casuarina spp. and Pandanus spp. in the driest areas, while on the limestone islands there is often high forest in which the vesi (Instia bijuga) is a prominent tree and the main source of timber for carving (Ash 1992; Ryan 2000).

It was expected that entry of people into the forested landscapes of Fiji, and the changes that occurred during human history, would be disclosed by sedimentary coring and palynological analysis. The evidence of such palaeoenvironmental investigations was regarded as vital to the overall objectives because it offered insight into two basic issues of island colonisation. The first was its potential value as an independent measure of colonisation chronology through radiocarbon-dating evidence of sedimentary and vegetational disturbance that was potentially of synanthropic origin. There was some disagreement in the mid-1990s about the interpretation of sedimentary and pollen sequences in the Pacific, notably about how to explain the considerable gap between palynological and archaeological chronologies of human colonisation in east Polynesia (e.g. Kirch and Ellison 1994; Anderson 1995) In Fiji, this was also a looming issue. Southern (1986) had a radiocarbon date of 4000 BP from the basal level of Bonatoa Bog, in the Rewa delta, where it was associated with a substantial level of fine charcoal under a decline in sago (Sagu vitiensis) pollen. Uncertainty was compounded by evidence, in pollen sequences from southern Viti Levu, of enigmatic perturbations that could be interpreted as cultural interference dating to as early as 4500 BP (Southern 1986; Shepherd 1990). The waters were muddied still further by arguments that the history of sea-level change was such that it was premature for prehistorians to rule out human colonisation during the last glacial era, when the Central Pacific archipelagos were several times larger and closer together than they are now (Gibbons 1985; Nunn 1994a, b).

More research on the specific issue of age and on the general pattern of anthropogenic disturbance was clearly needed. There were diverse opinions about the later vegetation history as well. Conventional wisdom had assigned the major role in formation of the modern lowland grasslands of New Caledonia and Fiji to anthropogenic burning (e.g. Cumberland 1963:196; Hughes et al. 1979; Ash 1992), but Latham (1983), Southern (1986) and Nunn (1994b) did not discount a largely natural origin for the extensive talasiga grasslands of the leeward districts of Viti Levu and on other islands.

Investigating the age and extent of deforestation in Holocene sequences was also important in other ways. Establishing the pattern of forest retreat could suggest whether it was 'front-loaded' 
into a general early clearance indicative of widespread exploration and use, or progressively cleared coastal to inland as might reflect population growth and agricultural expansion. Searching for pollen of introduced plants would help to estimate the timing and character of agricultural development.

\section{Fieldwork}

In July-August 1995, Hope and Anderson (1995; Hope et al. 2000) cored eight swamp localities in Viti Levu and Vanua Levu to obtain palynological sequences from which a more comprehensive picture of coastal vegetation change during the pre- and post-human Holocene could be constructed. The cores were also intended as a test of the Southern (1986) hypothesis of pre-Lapita intervention in coastal vegetation. In July 1996, Hope cored the Volivoli swamp at Sigatoka and a mangrove location near the Natunuku site at the mouth of the Ba River to investigate the effects of Lapita occupation on the local environment. In November 2000, Hope took a core from the flood plain near the Navatu 17A site to investigate the effects of postLapita human settlement, and undertook additional work in the Sigatoka Valley. In NovemberDecember 2000, Hope took cores from Vanuabalavu and Yacata in northern Lau.

\section{Human colonisation and cultural transformation}

When the Fiji project began, only a handful of Lapita sites had been examined archaeologically in any detail: Natunuku (Mead et al. 1973; Davidson et al. 1990), Sigatoka (Birks 1973), Yanuca (Birks and Birks 1978; Hunt 1980), Lakeba (Best 1984) and Naigani (Best 1981), although some additional sites had been recorded. The Sigatoka ceramic sequence had been used to define a Fijian culture history (Green 1963a, b; Green and Palmer 1964) comprising Lapita and plainware assemblages in the Sigatoka phase (1200-100 BC), paddle-impressed wares in the Navatu phase (100 BC-AD 1100), incised and shell-impressed assemblages in the Vuda phase (AD 1100-1800), and ornate modern wares in the Ra phase (about AD 1800-1900). Excavations by Birks (1973) put more precise dates to the two early phases, at least at Sigatoka: Level 1 (Sigatoka phase) radiocarbon dating to 789-405 BC (GaK-946, 2460 90 BP) and Level 2 (Navatu phase) dating to about $300 \mathrm{AD}$. He estimated Level 3 (Vuda phase) as about $1300 \mathrm{AD}$.

Radiocarbon dating of other Lapita sites suggested colonisation had begun earlier than 1000 BC. Among the Fijian Lapita dates listed by Kirch and Hunt (1988:Table 2.3) was an early age (GaK-1218, 3240 $100 \mathrm{BP})$, calibrated as 1684-1416 BC from the basal cultural layer 6 at Natunuku (recalculated by Davidson et al. (1990:131) as 1736-1266 BC), and another of

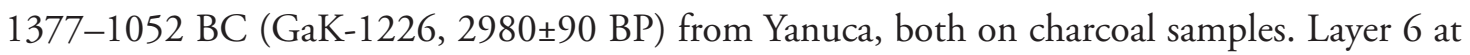
Natunuku produced a ceramic assemblage of early eastern Lapita type, with some connections to western Lapita, which was possibly older than other Fijian assemblages known at the time (Davidson et al. 1990). New dates on marine-shell samples from Layer 5 at Natunuku provided a much younger age, about $350 \mathrm{BC}$ (Davidson and Leach 1993), which simply highlighted the fact that in these sites and generally '. . . the Fijian sequence cannot yet be said to be well-dated' (Davidson and Leach 1993:102). Clearly one fundamental issue in understanding the early prehistory of Fiji had to be whether it was possible to obtain a more precise chronology of colonisation using various chronometric techniques in conjunction with evidence from site stratigraphy and material culture. As the Fiji archipelago is extensive, a related issue was whether there was evidence of delay in the initial colonisation of west versus east, or of small versus large islands.

Related to those matters was a cluster of questions about Lapita settlement patterns in general. Were they as exclusively coastal as they appeared, and was this more or less so in Remote Oceania where an absence of pre-existing inland occupation could be assumed? Was Lapita 
occupation largely associated with small islands? What did the answers to these questions imply about the nature of subsistence and about social patterns? Birks (1973) had used the Sigatoka dunes sequence to propose a dynamic model of Fijian prehistory, which argued that relatively slow dune formation in early prehistory followed by late rapid change indicated an increased rate of erosion in the Sigatoka catchment due to forest firing, which, in turn, reflected relatively late population growth and settlement penetration into the island interior (Figure 2). To put it another way, Lapita settlement was very much coastally tethered.

Yet it was difficult to avoid pondering the significance of the location of Natunuku and Sigatoka Lapita sites at the mouths of two of the largest rivers on Viti Levu (Sigatoka and Ba), where reef resources must have been comparatively poor even at the beginning of occupation, but where there was unparalleled watercraft access far into the interior. Looking at Lapita sites in general, Lepofsky (1988) had found that all were coastal and had ready access to the open sea, but there was no particularly evident proximity to reefal and lagoonal resources, arable land was generally close by, and a locational emphasis on small islands was less apparent than was generally believed. Other syntheses of Lapita site characteristics (Butler 1988; Nagaoka 1988) showed that faunal remains were relatively sparse overall and lent no strong support to either of the competing hypotheses: that Lapita expansion was fuelled largely by littoral and marine foraging - the so-called 'strandlooper hypothesis' (Groube 1971); or that it was mainly an agricultural expansion (Green 1979; Kirch and Green 1987), as documented by remains of introduced animals. As Kirch pointed out (1988:160), the evidence for horticulture, which was the core strategy at issue, remained indirect. As for social interaction, the coastal location of Lapita sites was clearly conducive to mobility by sea (Lepofsky 1988), but whether lithics and ceramics had been moved about within the Fijian archipelago (Hunt 1980; Best 1984) or from further afield, or were mainly of local procurement or manufacture, was a question that needed to be addressed.

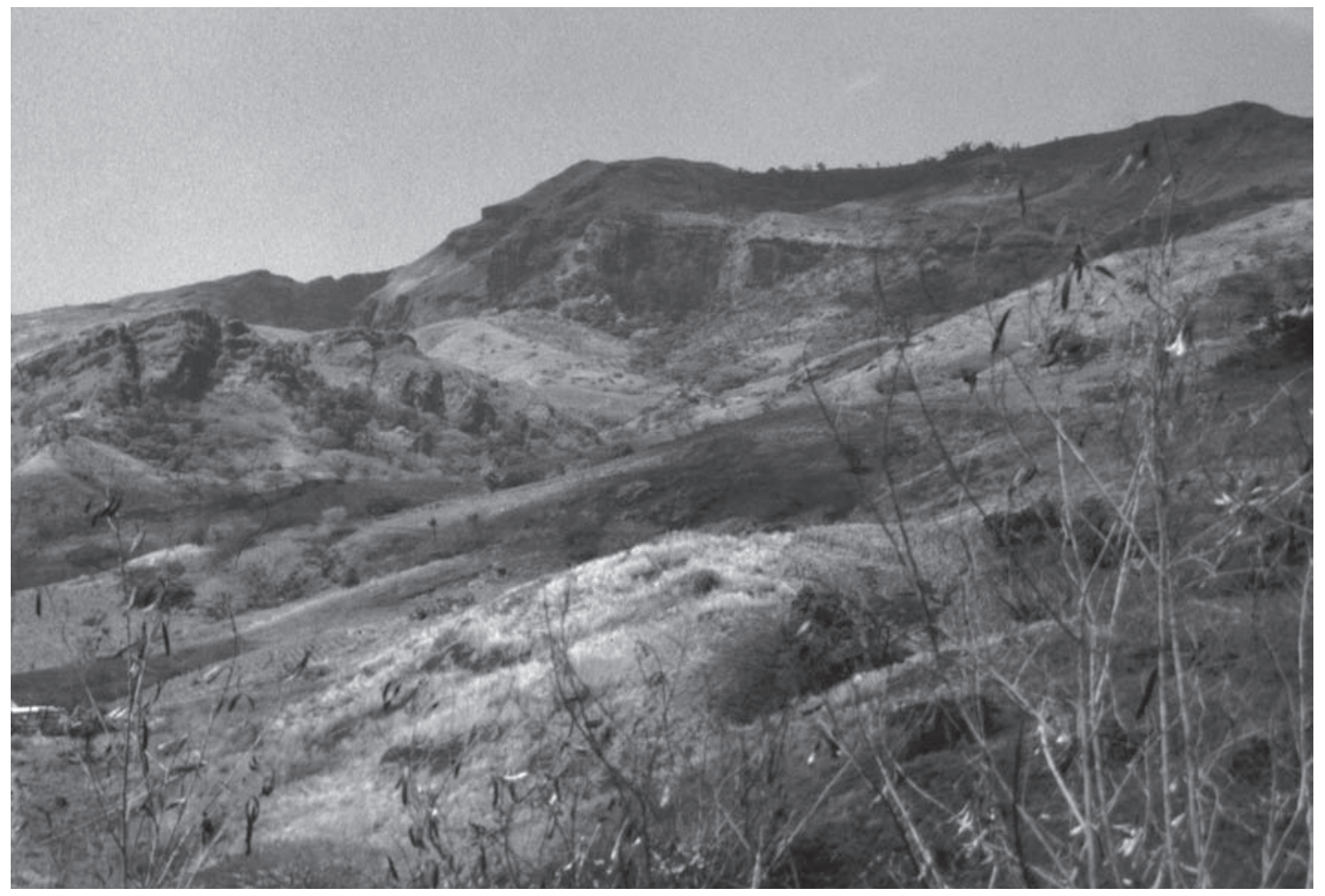

Figure 2. View of the landscape inland from the Sigatoka Sand Dunes. 
Fieldwork - Lapita sites

Archaeological fieldwork began in July 1996 with investigations at the two Lapita sites best known from previous research, Natunuku and Sigatoka, with the objective of defining more precisely the nature of the early Lapita phase in Fiji (or, indeed, of any earlier phase of settlement) in terms of both chronology and content. At Sigatoka (Figure 3), on the windward coast of Viti Levu, early archaeological remains are stratified in the lower levels of a coastal dune system and appear to represent periods of relative stability. Since dune-building began earlier than the lowest archaeological deposits, it was essential to determine whether there were phases of similar stability lower in the sequence than the archaeological remains and therefore whether there were prior periods when the locality could have been settled had there been people available to do so. The main objectives in this work were to obtain sediment profiles and samples and to date the changes. To do this we took samples for the (then quite new) method of optically stimulated luminescence dating, the only practical means of getting a detailed chronology of the dune system. Concurrently with work at Sigatoka were test excavations in the vicinity, at Malaqereqere rock shelter (Figure 4) along the coast to the west, and at two rock shelters in the Volivoli limestone massif behind Sigatoka (Volivoli I and Volivoli II). The purpose of these was to determine whether Lapita occupation could be picked up away from the main site along the coast or immediately inland in the lower Sigatoka Valley.
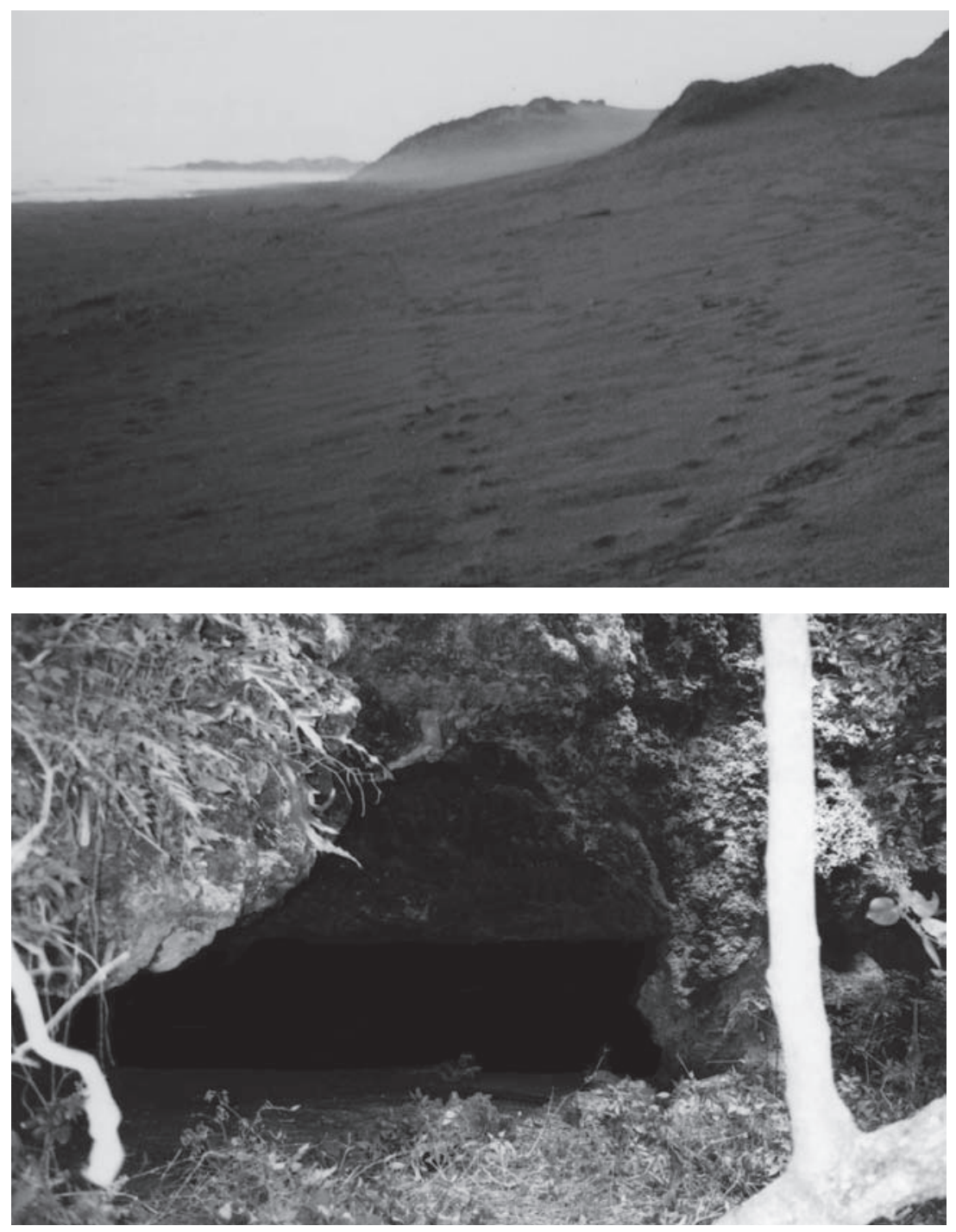

Figure 3. Sigatoka Sand Dune in south Viti Levu, west view along dunes.

Figure 4. Malaqereqere rock shelter prior to excavation. 
At Natunuku, on the leeward coast, were the eroding remains of a once-larger site (Mead et al. 1973), possibly the oldest in Fiji. Our objective was to locate and excavate additional areas of Layer 6 which had produced the very early radiocarbon date and to test sediments beneath for any earlier signs of occupation. We also wanted to date the sedimentary history of the site and beneath it using OSL dating. On a small coastal plain immediately behind the Lapita site another extensive site (approximately $1.0 \mathrm{ha}$ ) was observed in 1995. There was no evidence that this was a Lapita site, but as it extended to within $20 \mathrm{~m}$ of Lapita Location C (Davidson et al. 1990), it could have concealed early cultural layers at depth and on that ground it needed to be investigated.

Fieldwork on the Navatu phase began in August 1996. The Navatu 17A site (Figure 5) containing paddle-impressed pottery was relocated and excavated by Clark and a small team from the Fiji Museum and villagers from Narewa and Vitawa.

In November-December 1997, the Votua Lapita site on Mago Island (Figure 6) was discovered and excavated during an expedition to the Lau Group organised by Professor Patrick

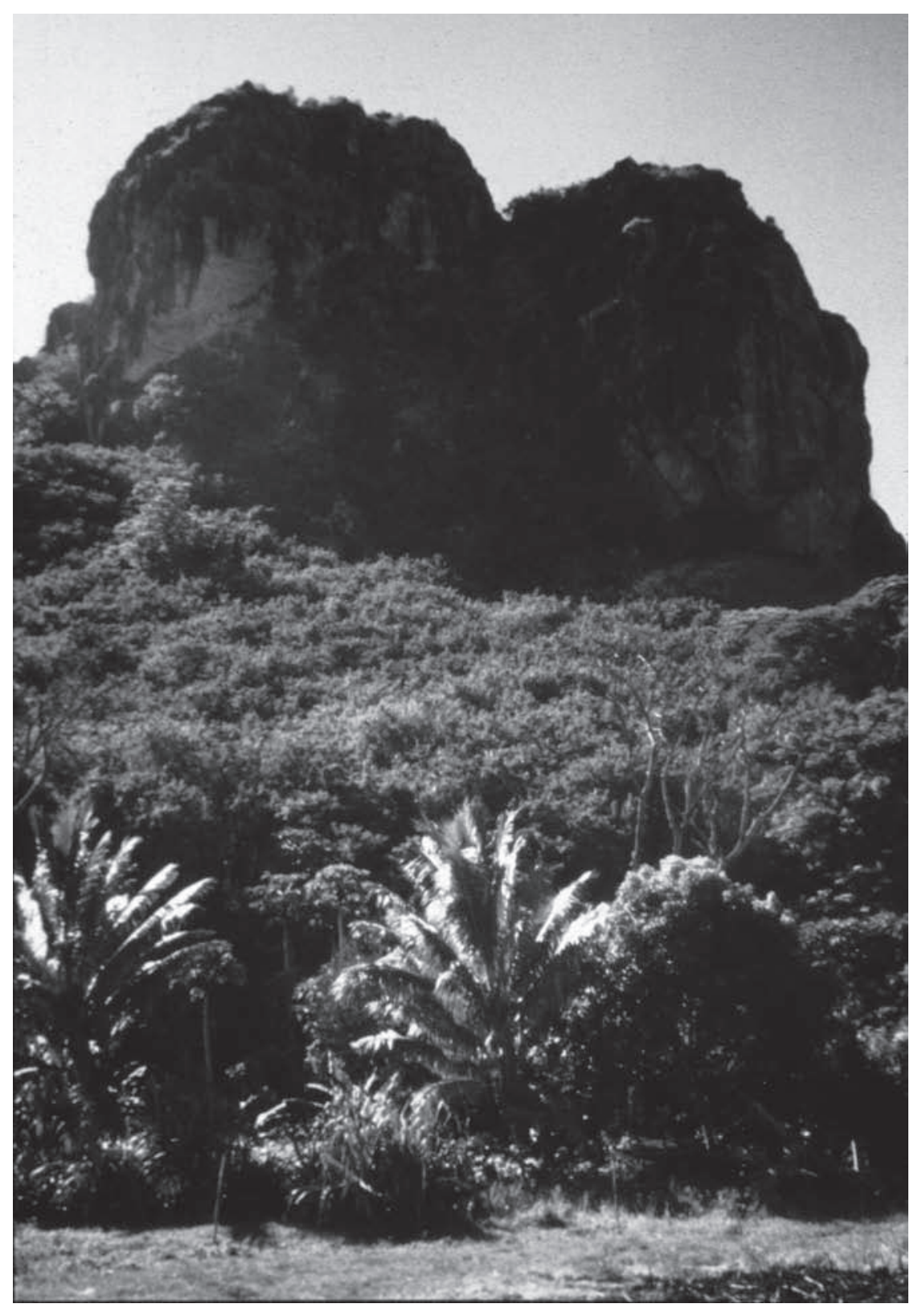

Figure 5. Uluinavatu volcanic plug in north Viti Levu. The Navatu 17 site is on the lower flanks of the plug just in from the edge of the sugar cane field. 
Nunn (USP). Deposits from the Sovanibeka rock shelter were collected by Clark and Hope. The Votua site was revisited in December 2000 and excavated by Clark, Hope and L. Schmidt (ANU). In May 1997, attention turned to Beqa Island (Figure 7), offshore from the south coast of Viti Levu. Lapita pottery had been reported from several localities by Crosby (1988). Two of these were especially interesting. One site in Kulu Bay was located in a damp area behind the coastal sand plain. This was targeted for an exploratory excavation to determine whether it was, or contained, a wet site of Lapita province.

Another site with early paddle-impressed wares was on the small lagoonal island of Ugaga (Figure 8). At this site, the transition from late Lapita to the middle phase of Fijian prehistory could be investigated.

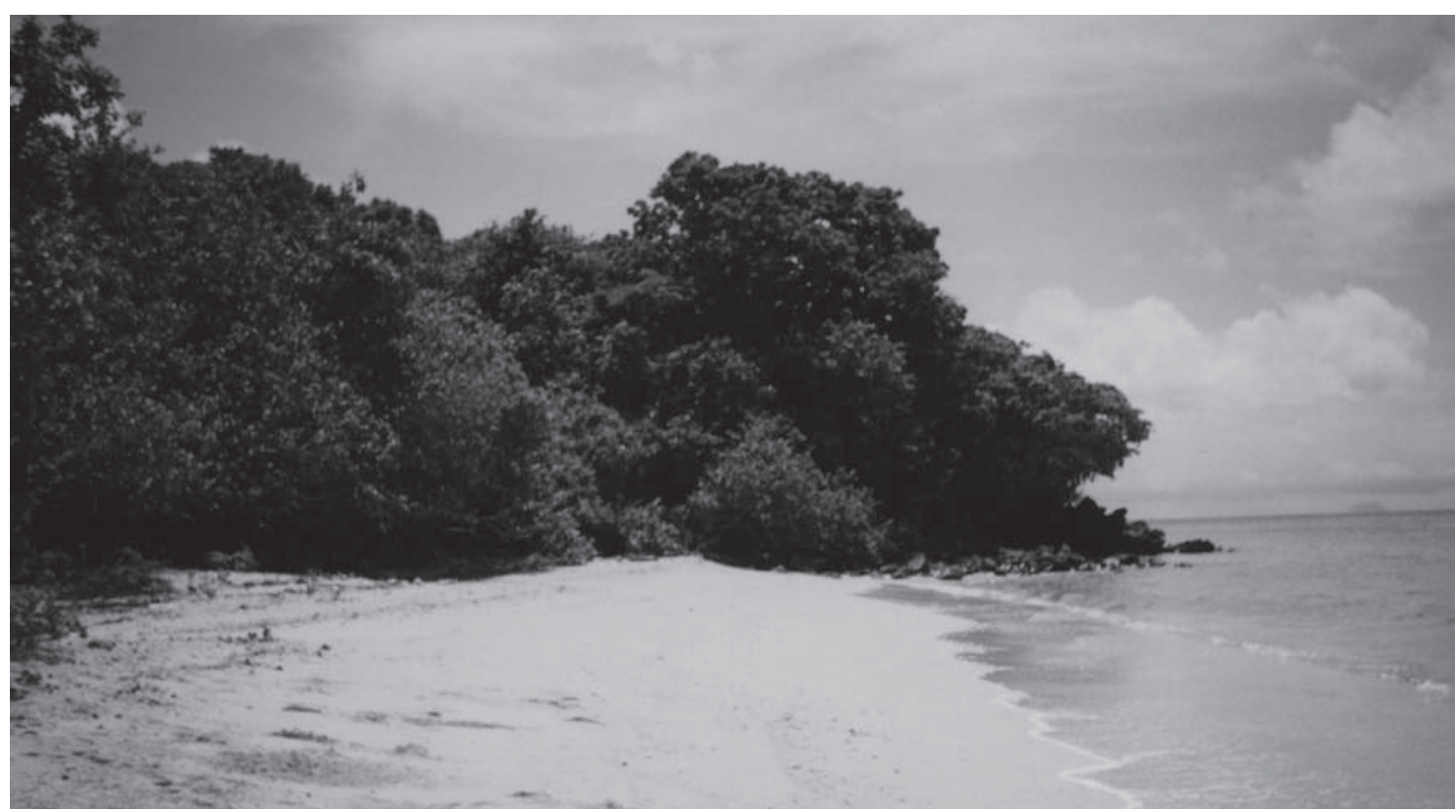

Figure 6. The Vutuna headland (west view) on Mago Island. The Votua Lapita site lies behind the beach berm beside the Tokelau Stream.

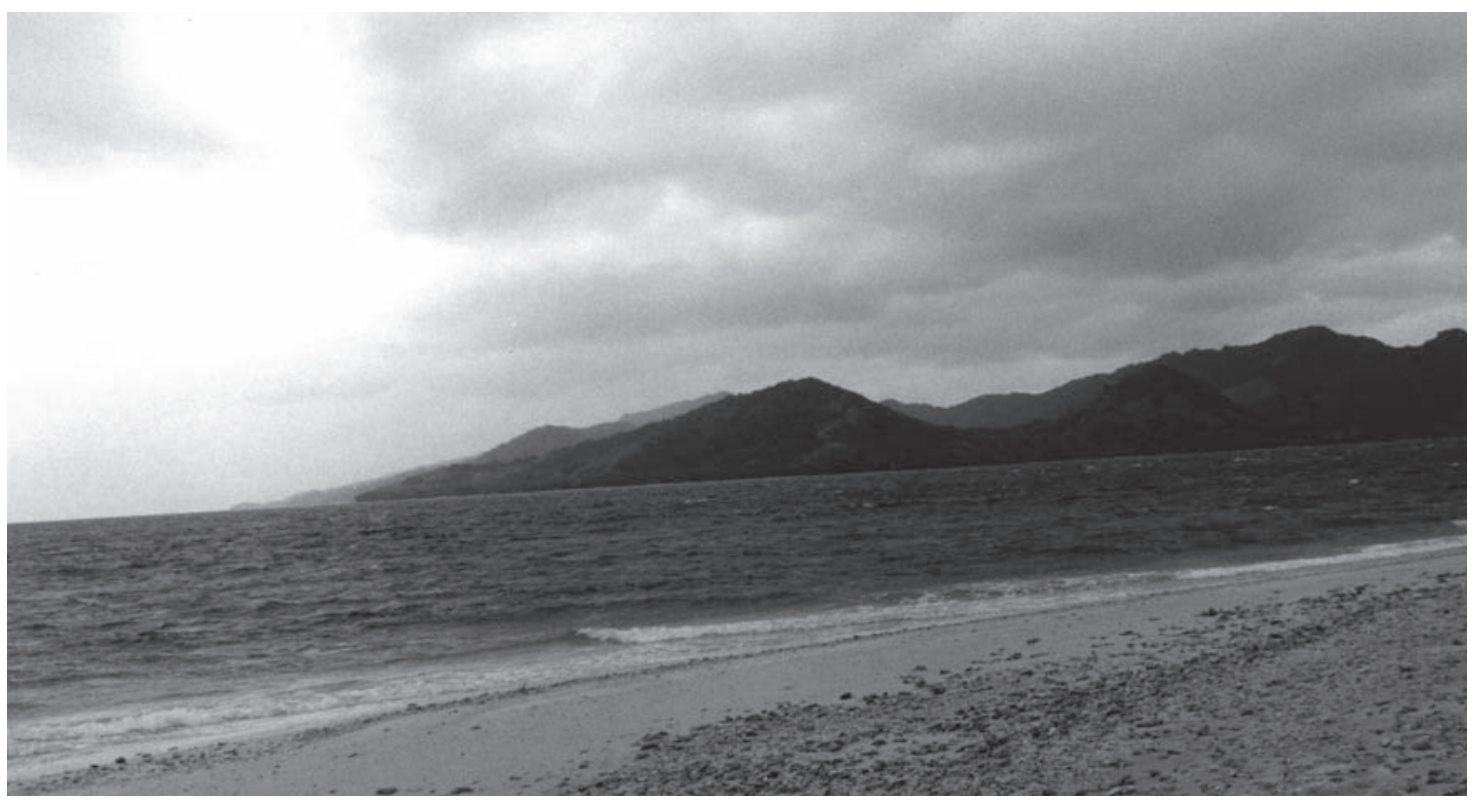

Figure 7. Beqa Island viewed from Ugaga Island. 


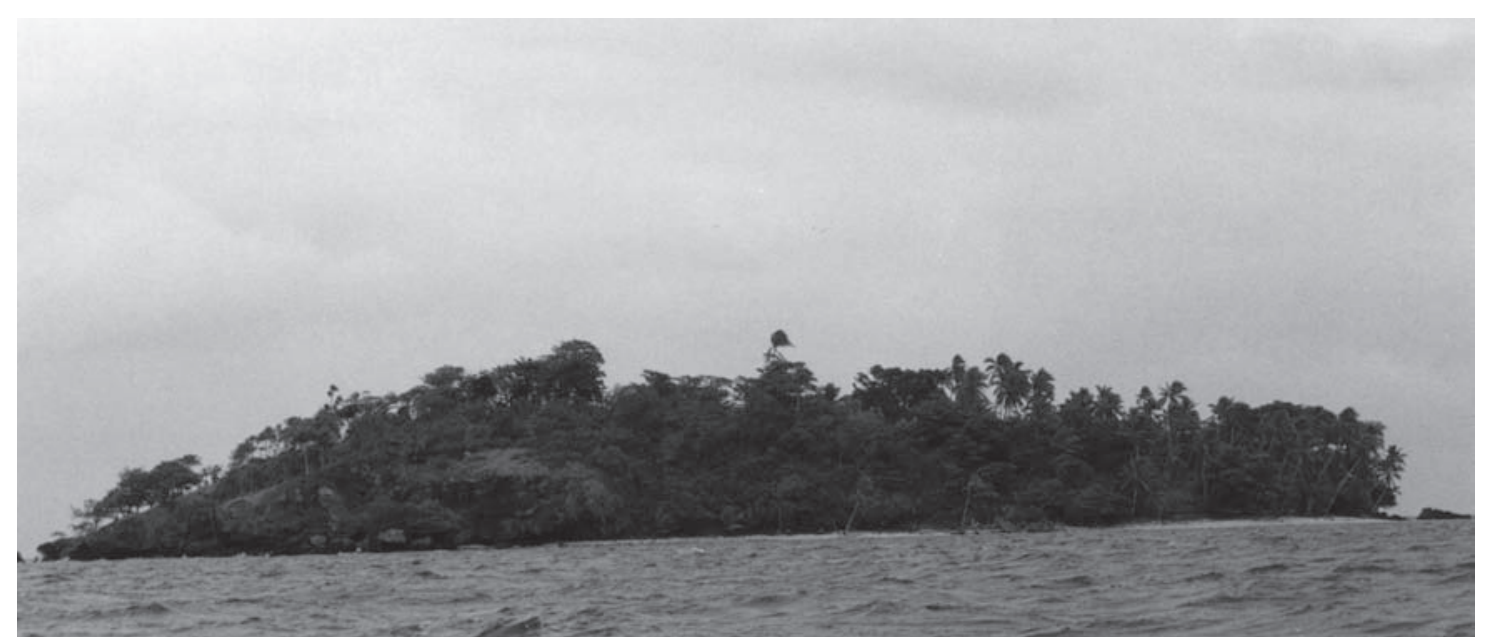

Figure 8. Ugaga Island in the Beqa Lagoon.

\section{Oceanic context}

Although a distinct project, the Fiji research was also part of the Indo-Pacific Colonisation Program (IPCP) devised by Anderson to pursue an interest in the late-Holocene migration of people, mostly presumed speakers of Austronesian languages, across the remote regions of the Indian and Pacific oceans, their colonisation of oceanic islands and the reciprocal relations that developed between settlement and environmental change. The IPCP originated in response to two concerns. The more important methodologically was that while oceanic archaeology structured as longitudinal culture-historical research by island or archipelago is fundamental to understanding regional prehistory, and it is certainly reflected in the Fiji project, it may not be the most useful way to investigate specific issues of extensive distribution, such as those of migration and colonisation, which are often, by their nature, relatively brief but wide-ranging. A project that focused on the scale of the oceanic landscape as a whole seemed a more useful and efficient approach. The Fiji research is interesting in its own right, but it will become, as well, part of the larger study of the prehistoric human colonisation of the oceans.

A more immediate and pragmatic concern was a crisis of research funding in 1995 that loomed in the Institute of Advanced Studies (ANU) because the institute had no direct access to the research funding through the Australian Research Council that was available to the ANU Faculties and all other Australian universities. Research survival demanded alternative resourcing strategies, a point driven home in 1996 by the reduction of the Division of Archaeology and Natural History to the status of a small department. The IPCP involved focused investigation of the colonising phases of numerous islands of various sizes, types and environmental zones, a strategy that required multiple, focused projects with shared resources in collaboration with colleagues with research interests across the island world.

Existing projects on Niue Island (Walter and Anderson 2002) and Norfolk Island (Anderson and White 2001) were taken into the IPCP and new projects were undertaken in Fiji, Christmas Island, Kiritimati Island (Anderson et al. 2002), Lord Howe Island, French Polynesia (Maupiti, Huahine, Mangareva, Rapa), the Pindai caves in New Caledonia, subantarctic New Zealand, Batanes Islands (Philippines), Yaeyama Islands (Japan), and the Juan Fernandez and Galapagos Islands of the far-eastern Pacific (Anderson 2004). The IPCP continues in the Indian Ocean. In due course, the Fiji project and all the others will be considered within a broad synthesis of the evidence and its implications for the human colonisation of the oceans. 


\section{Acknowledgments}

'The Early Prehistory of Fiji' project, directed by Atholl Anderson (Department of Archaeology and Natural History, ANU), received research funding from the Australian Research Council (with P. White), the Royal Society of New Zealand, the Wenner-Gren organisation and the National Geographic Society, for which we are most grateful. Staff at the Fiji Museum were instrumental in facilitating project fieldwork. In particular, we thank K. Vusoniwailala (Director), T. Sorovi-Vunidilo (Director, archaeologist), C. Burke (archaeologist), S. Matararaba (Mata) (Field Officer, archaeologist), J. Naucabalavu (Field Officer, archaeologist), W. Copeland and K. Nanda (Education Officer). We are very appreciative of the generous support of Professor P. Nunn (University of the South Pacific) who supported investigations at several locations and arranged site permissions and logistics, as well as providing study materials and student assistants. Significant assistance and advice was also provided by D. Watling, P. Geraghty, G. Udy, D. Burley, C. Ollier, P. Ryan, P. Rodda, W. Dickinson, R. Green, J. Clark, G. Irwin, C. Sand, A. Parke, S. Best, D. Argue, A. de Biran and F. Valentin, who gave generously of their time and knowledge. We are especially thankful to L. Schmidt and D. O'Dea in the Department of Archaeology and Natural History for assisting in the processing of archaeological and palaeoenvironmental materials.

We also thank the Roko Tui Nadroga/Navosa, Mr I. Kedralevu and the Provincial Officers, U. Kunaturaga, S. Moceacagi and M. Nagata, for helping with access to the Sigatoka sites. We are grateful for the aid of the Assistant Roko Tui Vuda/Vitoga, Mr S. Vaturu, for facilitating access to Nawaqadamu village, and thank, from Nawaqadamu village, Mr J. Nanauwalu (Turangini-koro), the Ratu M. Bitu, and the guides A. Raakuma and A. Kuruisaqila for access to caves in their care, particularly Vatumu Cave. Thanks are due to the following landowners who gave access to their lands and caves. Volivoli - Mrs L. Tubou (owner), Mr N. Tubou and Mr S. Batimala (Turanga-ni-koro); Wainibuku Area-Mr D. Singh, K. Vukeiono; Wailotua - Ratu A. Roseru and E. Cavu. We are grateful to H. Crawford and M. Livingston for hosting the team at Vatulele Resort while we conducted fieldwork. We thank the Ratu A. Racara-Tui of Ekubu village for permission to visit caves in the area, and for help in locating the caves we acknowledge P. Niutoga, A. Yabaki and A. Venuki.

The University of the South Pacific is thanked for funding the Northern Lau expedition headed by Professor P. Nunn, and the Tokyu Corporation of Japan is acknowledged for allowing research on Mago Island. The people of Mago, Yacata and Kaibu gave generously of their time, knowledge and hospitality during project investigations. The village of Naceva generously hosted the excavation crew during fieldwork on Beqa-Ugaga. Special thanks go to the Roko Tui Rewa, J. Cagi, V. Qaranivalu (village headman), P. Vakaolo, M. Tubanavau (Rukua village), J. Ledua Cagi, Professor M. Davis (Sociology, USP), J. Clark, N. Lawson, F. Ericsson, J. Naucabalavu, S. Mataraba, K. Lawson, Dr R. McGovern-Wilson (DoC, New Zealand). Excavations at Navatu were organised and carried out with the assistance of the Fiji Museum and thanks go to the people of Narewa village, particularly the late I. Donu who looked after the field crew of G. Clark, H. Kiguchi (JOCV-Fiji Museum), S. Matararaba, J. Nancabalaru, C. Tuitubou, V. Sadrugu, J. Tikoibau (Narewa) and V. Vakabua (Vitawa).

The palaeofaunal investigations were advanced by the assistance of curators and collections managers in the following institutions: Australian National University (ANU) - C. Campbell; Auckland Institute and Museum (AIM) - B. Gill; American Museum of Natural History (AMNH) - P. Sweet, A. Andors, C. Blake; Australian National Wildlife Collection, Canberra (ANWC) - J. Wombley; Natural History Museum, London (BMNH) - J. Cooper for measurements 
and X-Rays of specimens; Canterbury Museum, Christchurch, NZ (CM) - G. Tunnicliffe; Museum of New Zealand Te Papa Tongarewa, Wellington, NZ (MNZ) - A. Tennyson, S. Bartle; Queensland Museum, Brisbane, Australia (QM) - S. van Dyke; Smithsonian Institution (USNM) - S. Olson, P. Angle, R. Crombie; South Australian Museum, SA, Australia (SAM) B. McHenry; Burke Museum, University of Washington, Seattle, USA (UWBM) - R. Faucett and C. Filardi.

We also thank S. Best for loans of casts of Naigani faunal material, G. Irwin for access to the Naigani collections, E.S. Gaffney for turtle identifications (American Museum of Natural History) and D. de Gusta (Stanford University) who examined and identified the human bone from Navatu. Chert samples were kindly provided by S. Best, J. Clark and C. Sand. The Fiji Museum is gratefully acknowledged for allowing us to examine chert artefacts from Sigatoka. Chert samples were prepared by W. Ambrose (ANU) with thanks to G. Summerhayes (University of Otago) for providing access to the Lucas Heights accelerator and to P. White (Sydney University) for undertaking the PIXIE/PIGME analysis. The Statistical Consulting Unit at the ANU and P. Sheppard (Auckland University) provided helpful advice on the chert data for which we are grateful. Analyses of various materials was made by W. Ambrose, J. Chappell, D. Kennett, G. Robertson, R. Roberts and L. Wallis whom we thank. Land-snail identifications for Volivoli II were made with access to the shell collections held at the Netherlands National Museum of Natural History, and we thank E. Gittenberger, W. Maasson and J. de Vos for their support and also S. Walker for discussion of coenobitid hermit crab behaviour. The late R. Green (University of Auckland) kindly located and copied the excavation documents for Karobo, and the Fiji Museum gave permission for the Karobo collection to be studied at the ANU.

We are grateful for assistance in the collection of pollen cores from F. Areki, J. Ash, A. de Biran, C. Burke, the late L. Cavu, C. Corby, R. Kumar, P. Nunn, S. Matararaba, N. Ram, L. Schmidt, E. Tawake, N. van Dijk and B. Weatherstone. We owe a particular debt of gratitude to the University of South Pacific, which supported Southern and Hope's work, and the Fiji Museum. Financial support for pollen dating was provided by AINSIE and the late John Head of the ANU.

\section{References}

Anderson, A.J. 1995. Current approaches in East Polynesian colonization research. Journal of the Polynesian Society 104: 110-132.

Anderson, A.J. 2001. Mobility models of Lapita migration. In: Clark, G.R., Anderson, A.J. and Vunidilo, T. (eds), The archaeology of Lapita dispersal in Oceania: Papers from the Fourth Lapita Conference. Terra Australis 17: 15-23.

Anderson, A.J. 2004. It's about time: The Indo-Pacific colonization project. In: Murray, T. (ed), Archaeology from Australia, pp. 3-17. La Trobe University, Melbourne.

Anderson, A.J., Ayliffe, L., Questiaux, D., Sorovi-Vunidilo, T., Spooner, N. and Worthy, T. 2001b. The terminal age of the Fijian megafauna. In: Anderson, A.J., Lilley, I. and O'Connor, S. (eds), Histories of old ages: Essays in honour of Rhys Jones, pp. 251-264. Pandanus Books, Canberra.

Anderson, A., Bedford, S., Clark, G., Lilley, I., Sand, C., Summerhayes, G. and Torrence, R. 2001. A list of Lapita sites containing dentate-stamped pottery. 2001a. In: Clark, G.R., Anderson, A.J. and Vunidilo, T. (eds). The archaeology of Lapita dispersal in Oceania, pp. 1-13. Terra Australis 17, Pandanus Press, Canberra. 
Anderson, A.J., Burke, C. and Clark, G.R. 1996. Prehistoric colonisation and settlement of Fiji: An initial report to the Fiji Museum. Unpublished report to the Fiji Museum, Suva.

Anderson, A.J. and Clark, G.R. 1999. The age of Lapita settlement in Fiji. Archaeology in Oceania 34: 31-39.

Anderson, A.J., Clark, G.R. and Worthy, T.H. 2000. An inland Lapita site in Fiji. Journal of the Polynesian Society 109: 311-316.

Anderson, A.J., Martinsson-Wallin, H. and Wallin, P. 2002. The prehistory of Kiritimati (Christmas) Island, Republic of Kiribati: Excavations and analyses. Occasional Papers of The Kon-Tiki Museum, Volume 6.

Anderson, A., Roberts, R., Dickinson, W., Clark, G., Burley, D., de Biran, A., Hope G. and Nunn, P. 2006. Times of sand: Sedimentary history and archaeology at the Sigatoka dunes, Fiji. Geoarchaeology 21: 131-154.

Anderson, A.J. and White, J.P. (eds) 2001. The prehistoric archaeology of Norfolk Island, Southwest Pacific. Supplement 27, Records of the Australian Museum.

Ash, J. 1992. Vegetation ecology of Fiji: Past, present and future perspectives. Pacific Science 46: $111-127$.

Balouet, J.C. and Olson, S.L. 1987. An extinct species of giant pigeon (Columbidae: Ducula) from archaeological deposits on Wallis (Uvea) Island, South Pacific. Proceedings of the Biological Society of Washington 100: 769-775.

Bellwood, P. 1996. Early agriculture and the dispersal of the southern Mongoloids. In: Akazawa, T. and Szathmáry, E. (eds), Prehistoric Mongoloid dispersals, pp. 287-302. Oxford University Press, Oxford.

Best, S. 1981. Excavations at Site VL 21/5 Naigani Island, Fiji, a preliminary report. Department of Anthropology, University of Auckland.

Best, S. 1984. Lakeba: The prehistory of a Fijian Island. Unpublished PhD thesis, Department of Anthropology, University of Auckland.

Birks, L. 1973. Archaeological excavations at Sigatoka dune site, Fiji. Bulletin of the Fiji Museum No.1.

Birks, L. and Birks, H. 1978. Archaeological excavations at site VL 16/81, Yanuca Island, Fiji. Oceanic Prehistory Records No. 6. University of Auckland.

Burley, D.V. 1997. Archaeological research, Sigatoka Sand Dune National Park. Unpublished report to the Fiji Museum, Suva.

Butler, V.L. 1988. Lapita fishing strategies: The faunal evidence. In: Kirch, P.V. and Hunt, T.L. (eds), Archaeology of the Lapita cultural complex: A critical review, pp. 99-115. Thomas Burke Memorial Washington State Museum Research Report No. 5. Burke Museum, Seattle.

Chase, C.G. 1971. Tectonic history of the Fiji Plateau. Geological Society of America Bulletin 82: 3087-3110.

Clark, G.R. 2000. Post-Lapita Fiji: Cultural transformation in the mid-sequence. Unpublished PhD thesis, Australian National University.

Clark, G. 2003. Shards of meaning: Archaeology and the Melanesia-Polynesia distinction. Journal of Pacific History 38(2): 197-213.

Clark, G.R. and Anderson, A.J. 2001 The pattern of Lapita settlement in Fiji. Archaeology in Oceania 36: $77-88$.

Clark, G.R., Anderson., A.J. and Matararaba, S. 2001. The Lapita site at Votua, northern Lau Islands, Fiji. Archaeology in Oceania 36: 134-143

Clark, J.T., Cole, A.O. and Nunn, P.D. 1999. Environmental change and human prehistory on Totoya Island, Fiji. In: Lilley, I. and Galipaud, J-C. (eds), Le pacifique de 5000 à 2000 avant le présent. Suppléments à l'histoire d'une colonisation, pp. 227-240. Editions de l'ORSTOM, Paris.

Crosby, A. 1988. Beqa: Archaeology, structure and history in Fiji. Unpublished MA thesis, Department of Anthropology, University of Auckland.

Cumberland, K.B. 1963. Man's role in modifying island environments in the southwest Pacific: With 
special reference to New Zealand, pp. 187-206. In Fosberg, F.R. (ed), Man's place in the island ecosystem, pp. 187-206. Bishop Museum, Honolulu.

Davidson, J., Hinds, E., Holdaway, S. and Leach, F. 1990. The Lapita site of Natunuku, Fiji. New Zealand Journal of Archaeology 12: 121-155.

Davidson, J. and Leach, F. 1993. The chronology of the Natunuku site, Fiji. New Zealand Journal of Archaeology 15: 99-105.

Dickinson, W.R., Burley, D.V. and Shutler, R. Jr. 1994. Impact of hydro-isostatic Holocene sea-level change on the geologic context of archaeological sites. Geoarchaeology 9: 85-111.

Ellison, J.C. 1989. Pollen analysis of mangrove sediments as a sea level indicator: Assessment from Tongatapu, Tonga. Palaeogeography, Palaeoclimatology, Palaeoecology 74(3-4): 327-341.

Flannery, T.F. 1995. Mammals of the South-west Pacific and Moluccan Islands. Reed Books in association with the Australian Museum, Sydney.

Frost, E.L. 1970. Archaeological excavations of fortified sites on Taveuni, Fiji. Unpublished PhD thesis, University of Oregon.

Frost, E.L. 1979. Fiji. In: Jennings, J.D. (ed), The prehistory of Polynesia, pp. 61-81. Australian National University Press, Canberra.

Garanger, J. 1971. Incised and applied-relief pottery, its chronology and development in southeastern Melanesia, and extra areal comparisons. In: Green, R.C. and Kelly, M. (eds), Studies in oceanic culture history, Volume 2, pp. 53-99. Pacific Anthropological Records No. 12.

Gibbons, J.R.H. 1985. A brief environmental history of Fiji. Domodomo III(3): 110-123.

Gibbons, J.R. and Clunie, F.G. 1986. Sea level changes and Pacific prehistory, new insight into early human settlement of Oceania. The Journal of Pacific History XXI (2): 58-82.

Gifford, E.W. 1951. Archaeological excavations in Fiji. University of California Anthropological Records 13: 189-288.

Gilbert, T. 1984. Limestone and volcanic caves of the Fiji Islands. Transactions of the British Cave Research Association 11(2): 105-118.

Golson, J. 1961. Report on New Zealand, western Polynesia, New Caledonia and Fiji. Asian Perspectives 5: $166-180$.

Golson, J. 1974. Both sides of the Wallace Line: New Guinea, Australia, Island Melanesia and Asian prehistory. In: Barnard, N. (ed), Early Chinese art and its possible influence in the Pacific Basin, pp. 533-595. Proceedings of a symposium arranged by the Department of Art History and Archaeology, Columbia University, New York City and Taiwan.

Gorham, S.W. 1965. Fiji frogs, life history data from field work. Zoologische Beitrage 14: 427-446.

Green, R.C. 1963a. A suggested revision of the Fiji sequence. Journal of the Polynesian Society 72: 235-253.

Green, R.C. 1963b. Two collections of pottery from Sigatoka, Fiji. Journal of the Polynesian Society 72: 261-264.

Green, R.C. 1979. Lapita. In: Jennings, J.D. (ed), The prehistory of Polynesia. pp. 27-60. Australian National University Press, Canberra.

Green, R.C. and Palmer, J.B. 1964. Fiji sequence: Corrections and additional notes for Sigatoka. Journal of the Polynesian Society 73: 328-333.

Green, R.C. and Richards, H.G. 1975. Lapita pottery and lower sea level in western Samoa. Pacific Science 29: 309-315.

Groube, L.M. 1971. Tonga, Lapita pottery, and Polynesian origins. Journal of the Polynesian Society 80: 278-316.

Hale, H. 1846. United States exploring expedition: Ethnology and philology. Lea and Blanchard, Philadelphia.

Hope, G. and Anderson, A. 1995. A reconnaissance survey of Holocene deposits on Viti Levu and Vanua Levu, Fiji. Unpublished report, Australian National University.

Hope, G., Anderson, A., Stevenson, J. and O’Dea, D. 2000. Vegetation histories from Fiji: Alternative records of human impact. Unpublished ANH working paper. 
Hope, G., O'Dea, D. and Southern, W. 1999. Holocene vegetation histories in the Western Pacific: Alternative records of human impact. In: Lilley, I. and Galipaud, J-C. (eds), The Pacific from 5000 to 2000 BP: Colonisation and transformations, pp. 387-404. IRD Editions, Paris.

Howe, K.R. 1984. Where the waves fall. Allen and Unwin, Sydney.

Howells, W. 1973. The Pacific Islanders. Weidenfeld and Nicolson, London.

Hudson, E. 1994. Sigatoka Sand Dune Site archaeological rescue project 1993. Unpublished report, Auckland Uniservices Limited, Auckland.

Hughes, P.J., Hope, G.S., Latham M. and Brookfield, M. 1979. Prehistoric man-induced degradation of the Lakeba landscape: Evidence from two inland swamps. In: Brookfield, H.G. (ed), Lakeba: Environmental change, population and resource use, pp. 93-111. UNESCO/UNFPA Island Reports 5.

Hunt, T.L. 1980. Toward Fiji's past: archaeological research on southwestern Viti Levu. Unpublished MA thesis, University of Auckland.

Hunt, T.L. 1986. Conceptual and substantive issues in Fijian prehistory. In: Kirch, P.V. (ed), Island societies: Archaeological approaches to evolution and transformation, pp. 20-32. Cambridge University Press, Cambridge.

Jennings, J.D. 1974. The Ferry Berth site, Mulifanua district, Upolu. In: Green, R.C. and Davidson, J.M. (eds), Archaeology in Western Samoa, Volume 2. Auckland Institute and Museum Bulletin 7: 176-178.

Kaeppler, A. 1978. Exchange patterns in goods and services: Fiji, Tonga and Samoa. Mankind 11: 246-252.

Kirch, P.V. 1988. Niuatoputapu: The prehistory of a Polynesian chiefdom. Thomas Burke Memorial Washington State Museum Monograph No. 5. The Burke Museum, Seattle.

Kirch, P.V. and Ellison, J. 1994. Palaeoenvironmental evidence for human colonization of remote Oceanic islands. Antiquity 68: 310-321.

Kirch, P.V. and Green, R.C. 1987. History, phylogeny and evolution in Polynesia. Current Anthropology 28: 431-456.

Kirch, P.V. and Hunt, T.L. 1988. The spatial and temporal boundaries of Lapita. In: Kirch, P.V. and Hunt, T.L. (eds), Archaeology of the Lapita cultural complex: A critical review, pp. 9-31. Thomas Burke Memorial Washington State Museum Research Report No. 5. Burke Museum, Seattle.

Koopman, K.F. and Steadman, D.W. 1995. Extinction and biogeography of bats on 'Eua, Kingdom of Tonga. American Museum Novitates 3125: 1-13.

Latham, M. 1983. Origin of the talasiqa formation. In: Latham, M. and Brookfield, H.C. (eds), The eastern islands of Fiji, pp. 129-142. UNESCO/UNFPA, Paris.

Lepofsky, D. 1988. The environmental context of Lapita settlement location. In: Kirch, P.V. and Hunt, T.L. (eds), Archaeology of the Lapita cultural complex: A critical review, pp. 33-47. Thomas Burke Memorial Washington State Museum Research Report No. 5. Burke Museum, Seattle.

Martin, J. 1817 An account of the natives of the Tongan Islands, compiled and arranged from the communications of Mr William Mariner, 2 vols. London.

Mead, S., Birks, L., Birks, H. and Shaw, E. 1973. The Lapita pottery style of Fiji and its associations. Journal of the Polynesian Society Memoir 38: 1-98.

Nagaoka, L. 1988. Lapita subsistence: The evidence of non-fish archaeofaunal remains. In: Kirch, P.V. and Hunt, T.L. (eds), Archaeology of the Lapita cultural complex: A critical review, pp. 117-153. Thomas Burke Memorial Washington State Museum Research Report No. 5. Burke Museum, Seattle.

Nunn, P.D. 1994a. Oceanic islands. Blackwell, Oxford.

Nunn, P.D. 1994b. Beyond the naive lands: Human history and environmental change in the Pacific

Basin. In: Waddell, E. and Nunn, P.D. (eds), The margin fades: Geographical itineraries in a world of islands, pp. 5-27. Institute of Pacific Studies, USP, Suva.

Nunn, P.D. 1999. Environmental change in the Pacific Basin. John Wiley, Chichester.

Pawley, A. and Ross, M. 1995. The prehistory of the Oceanic languages: A current view. In: Bellwood, 
P., Fox J.J. and Pawley, A. (eds), The Austronesians: Historical and comparartive perspectives, pp. 39-74. Anthropology, RSPAS, ANU, Canberra.

Pernetta, J.C. and Watling, D. 1979. The introduced and native terrestrial vertebrates of Fiji. Pacific Science 32: 223-244.

Petchey, F. 1995. Archaeology of Kudon: Archaeological analysis of Lapita ceramics from Mulifanua, Samoa and Sigatoka, Fiji. Unpublished MA thesis, University of Auckland, New Zealand.

Poulsen, J. 1987. Early Tongan prehistory. (2 volumes). Terra Australis 12. Department of Prehistory, Research School of Pacific Studies, Australian National University.

Pregill, G.K. 1993. Fossil lizards from the late Quaternary of 'Eua, Tonga. Pacific Science 47: 101-114.

Pregill, G.K. and Dye, T. 1989. Prehistoric extinction of giant iguanas in Tonga. Copeia 1989: 505-508.

Rodda, P. 1994. Geology of Fiji. In: Stevenson, A.J., Herzer, R.H. and Ballance, P.F. (eds), Geology and submarine resources of the Tonga-Lau-Fiji Region. SOPAC Technical Bulletin 8: 131-151.

Ryan, P. 2000. Fijis natural heritage. Southwestern, Auckland.

Shepherd, M.J. 1990. The evolution of a moderate energy coast in Holocene time; Pacific Harbour, Viti Levu, Fiji. New Zealand Journal of Geology and Geophysics 33: 547-556.

Shutler, R. Jr., Burley, D.V., Dickinson, W.R., Nelson, E. and Carlson, A.K. 1994. Early Lapita sites, the colonisation of Tonga and recent data from northern Ha'apai. Archaeology in Oceania 29: 53-68.

Solheim, W.G. II. 1952a. Oceanian pottery manufacture. Journal of East Asiatic Studies. 1(2): 1-39.

Solheim, W.G. II. 1952b. Paddle decoration of pottery. Journal of East Asiatic Studies. 2(1): 35-45.

Southern, W. 1986. The late Quaternary environmental history of Fiji. Unpublished doctoral dissertation, Australian National University.

Spriggs, M. 1997. The Island Melanesians. Blackwell, Oxford.

Steadman, D.W. 1993. Biogeography of Tongan birds before and after human impact. Proceedings of the National Academy of Sciences, USA 90: 818-822.

Steadman, D.W. 1994. Bird bones from the To'aga site, Ofu, American Samoa: Prehistoric loss of seabirds and megapodes. University of California Archaeological Research Facility, Contributions 51: 217-228.

Steadman, D.W. 1995: Prehistoric extinctions of Pacific island birds: Biodiversity meets zooarchaeology. Science 267: 1123-1131.

Steadman, D.W., Worthy, T.H., Anderson, A.J. and Walter, R. 2000. New species and records of birds from prehistoric sites on Niue, Southwest Pacific. Wilson Bulletin 112: 165-186.

Vanderwal, R.L. 1973. Prehistoric studies in central coastal Papua. Unpublished PhD thesis, Australian National University.

Wahome, E.W. 1997. Continuity and change in Lapita and post-Lapita ceramics: A review of evidence from the Admiralty Islands and New Ireland, Papua New Guinea. Archaeology in Oceania 32(1): $118-123$.

Wahome, E.W. 1998. Ceramic and prehistoric exchange in the Admiralty Islands, Papua New Guinea. Unpublished $\mathrm{PhD}$ thesis, Australian National University.

Walter, R. and Anderson, A. 2002. The archaeology of Niue Island West Polynesia. Bishop Museum Bulletin in Anthropology 10. Bishop Museum Press, Honolulu.

Watling, D. 1982. Birds of Fiji, Tonga and Samoa, Millwood Press, Wellington.

Wood, S., Marshall, Y. and Crosby, A. 1998. Mapping Sigatoka Site VL 16/1: The 1992 field season and its implications. Unpublished report, Fiji Museum, Suva.

Worthy, T.H. 2000. Fossil faunas from Vatulele Island, Fiji. Unpublished report, Fiji Museum, Suva,.

Worthy, T.H. and Anderson, A.J. 1999. Research on the caves of Viti Levu, Fiji, June 1997-October 1998, and their significance for palaeontology and archaeology. Unpublished Report, Fiji Museum, Suva.

Worthy, T.H., Anderson, A.J. and Molnar, R.E. 1999. Megafaunal expression in a land without mammals: The first fossil faunas from terrestrial deposits in Fiji (Vertebrata: amphipibia, reptilia, aves). Senckenbergiana biologica 79: 237-242. 